\title{
EXPERIMENTAL STUDY OF ELECTRICAL DISCHARGE MACHINING ON STAINLESS STEEL WORKPIECE USING ONE PARAMETER AT A TIME APPROACH
}

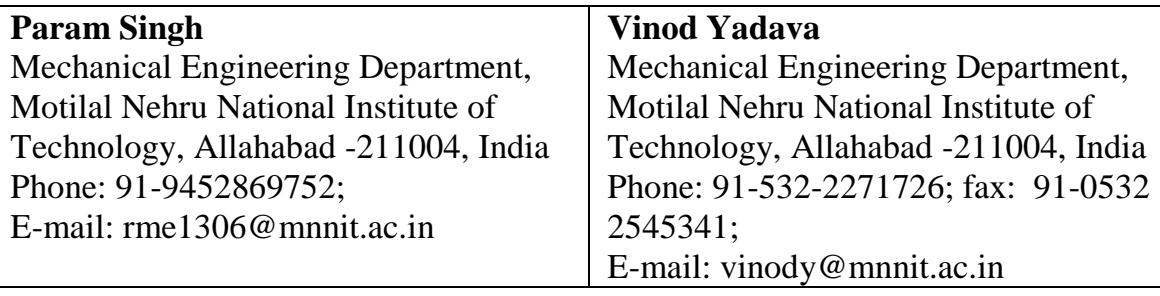

\author{
Vinod Yadava \\ Mechanical Engineering Department, \\ Motilal Nehru National Institute of \\ Technology, Allahabad -211004, India \\ Phone: 91-532-2271726; fax: 91-0532 \\ 2545341; \\ E-mail: vinody@mnnit.ac.in
}

\author{
Audhesh Narayan \\ Mechanical Engineering Department, \\ Motilal Nehru National Institute of \\ Technology, Allahabad -211004, India \\ Phone: 0532-227152; \\ E-mail: anarayan@mnnit.ac.in
}

\begin{abstract}
Electrical discharge machining (EDM) is one of the important non-conventional material removal processes and it is widely accepted as a standard manufacturing process in the machining of difficult to machine electrically conductive materials using thermal energy generated by spark between two electrodes completely dipped in dielectric and applying pulsating voltage between them. This present work is devoted to a study of the influences of EDM parameters on Material Removal Rate (MRR) and Surface Roughness (SR) for machining of 202 stainless steel as a workpiece with copper tool. The selected EDM input parameters were pulsed current (A), pulse on time ( $\mu s)$, pulse off time ( $\mu s)$ and tool rotation (rpm).One parameter at a time study was performed to observe the responses with the variation in the selected input parameters. Experimental investigations showed that for higher MRR there were high pulse current, high pulse on time, high RPM and low pulse off time and for the better surface finish there were low pulse current, low pulse on time, low pulse off time and low RPM.
\end{abstract}

Keywords-EDM, Material Removal Rate, Pulse on time, Pulse off time, Pulse current, Surface roughness, Tool rotation, 202stainless steel

\section{INTRODUCTION}

EDM is a thermoelectric process in which heat energy of a spark is used to remove material from the electrically conductive workpiece. A spark is produced between two electrodes where surface irregularities of these find the narrowest gap between the two. Each spark generates temperature more than $10,000^{\circ} \mathrm{C}$ which is sufficient to melt and vaporize any hard and difficult to machine electrically conductive material. The material is removed in the form of crater which flushed away with the help of non-conducting dielectric [1].

It is a basic machining method for the manufacturing industries of aerospace, automotive, nuclear, medical and die-mold production and for machining of heat treated tool steel and advanced materials (super alloys, ceramics, and metal matrix composites) requiring high precision, complex shapes and high surface finish [3,4].
Being all these advantages it is restricted its further application due to its low machining efficiency and poor surface finish. There are many published studies which show selection of optimum parameters from experimental data. Many optimization techniques used to optimize the machining performance [6].

Due to have high tensile strength, durability and corrosion resistance 202 stainless steel is used in many industrial, commercial and domestic fields. In this paper electric discharge drilling is performed on 202 stainless steel workpiece by using cupper as the tool electrode and one parameter at a time study has been done for observing how to material removal rate and surface finish vary with selected input parameters.

\section{EXPERIMENTATION}

For experimentation purpose ECOLINE ZNC Sinker-320 EDM Machine was utilized (fig.1).Electrical Discharge drilling setup is mounted on the ram of this machine (fig.2). Electrical permanent DC motor of $0.25 \mathrm{hp}$ Rotomag (India) of 1500 (RPM), electrically conductive tool electrode, rotating spindle cum tool electrode holder mechanism, mounted on the ram of the EDM machine.

In present experiment copper tool and stainless steel $202 \mathrm{G}$ workpiece were used. Experiments were conducted with positive polarity of tool electrode. Selected input parameters were pulse current (A), Pulse on time $\mathrm{T}_{\text {on }}(\mu \mathrm{s})$, Pulse off time $\mathrm{T}_{\text {off }}(\mu \mathrm{s})$, and tool rotation (rpm) and the output machining parameters were material removal rate (MRR), and surface roughness (Ra).For the measurement of surface roughness, surface roughness tester (Surtronic-25 model, Tayler Hobson Ltd, UK) with accuracy $0.01 \mu \mathrm{m}$ was used. Material removal rate (MRR) in $\mathrm{mm}^{3} / \mathrm{min}$ calculated by the following formula:-

\section{$\mathrm{MRR}=$}

Where $W_{W}$ is the workpiece weight loss in gms, $\rho$ is the workpiece material density in $\mathrm{gm} / \mathrm{cm}^{3}$ and $\mathrm{T}$ is the 
ELK

\section{Asia Pacific Journals}

machining time in min. Measurement of weight of the workpiece has been done on digital micro-balance

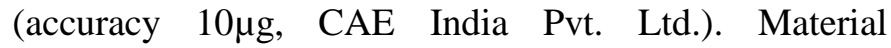
composition of 202stainless steel is shown in table 1.

There are many numbers of factors to involve in the discharge machining process. In this work, pulse current (A), pulse on time ( $\mu \mathrm{s})$, pulse off time ( $\mu \mathrm{s})$ and tool rotation (rpm) have only been taken into the account. Because, these factors have major responsibility in thermal erosion process as those of factors were being selected as input parameters among many researchers. Material removal rate (MRR) and Surface roughness (Ra) have been selected as response parameters. Table 2 shows the process variables with their levels.

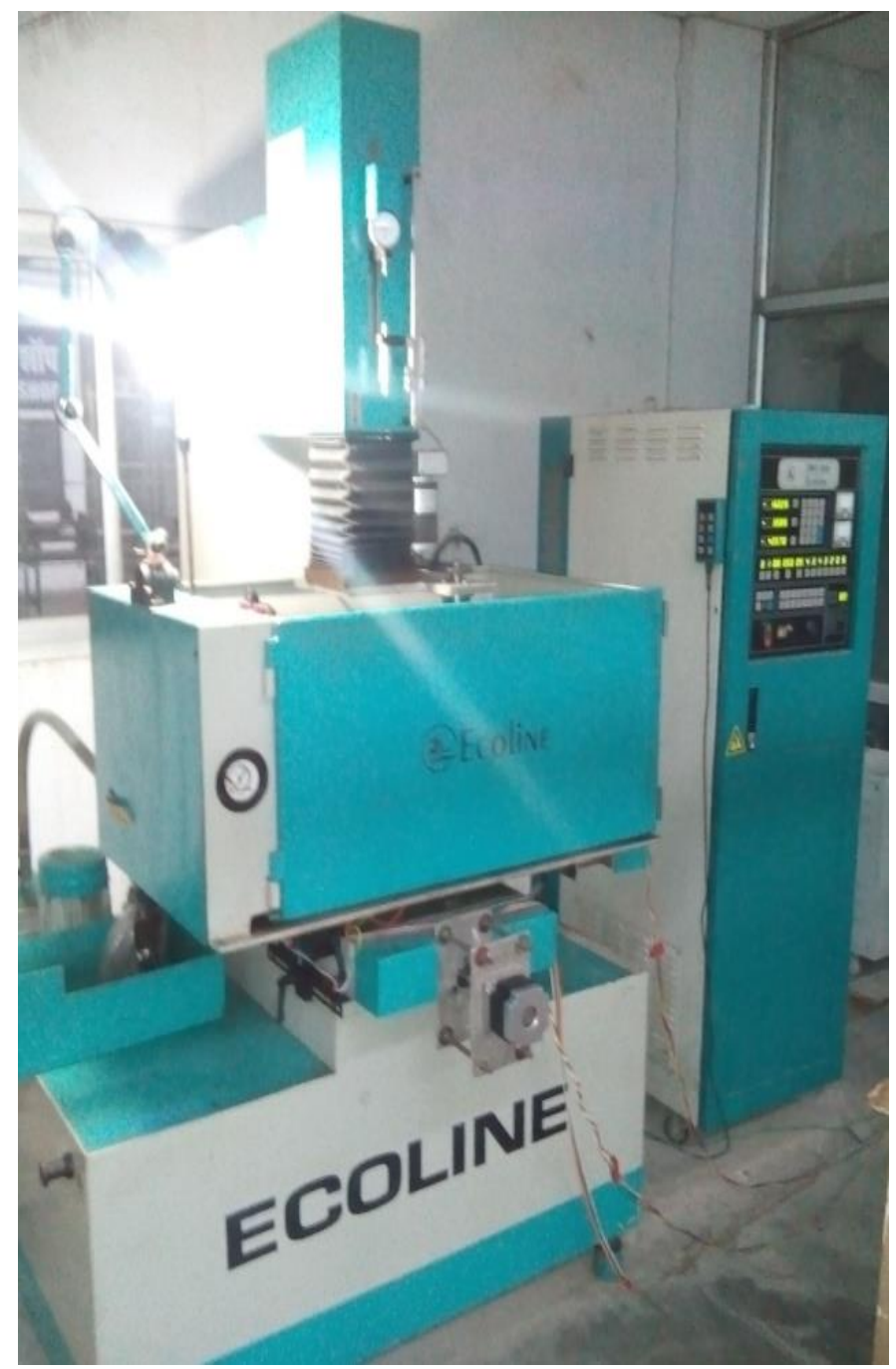

Fig.1 EDM Machine used under study

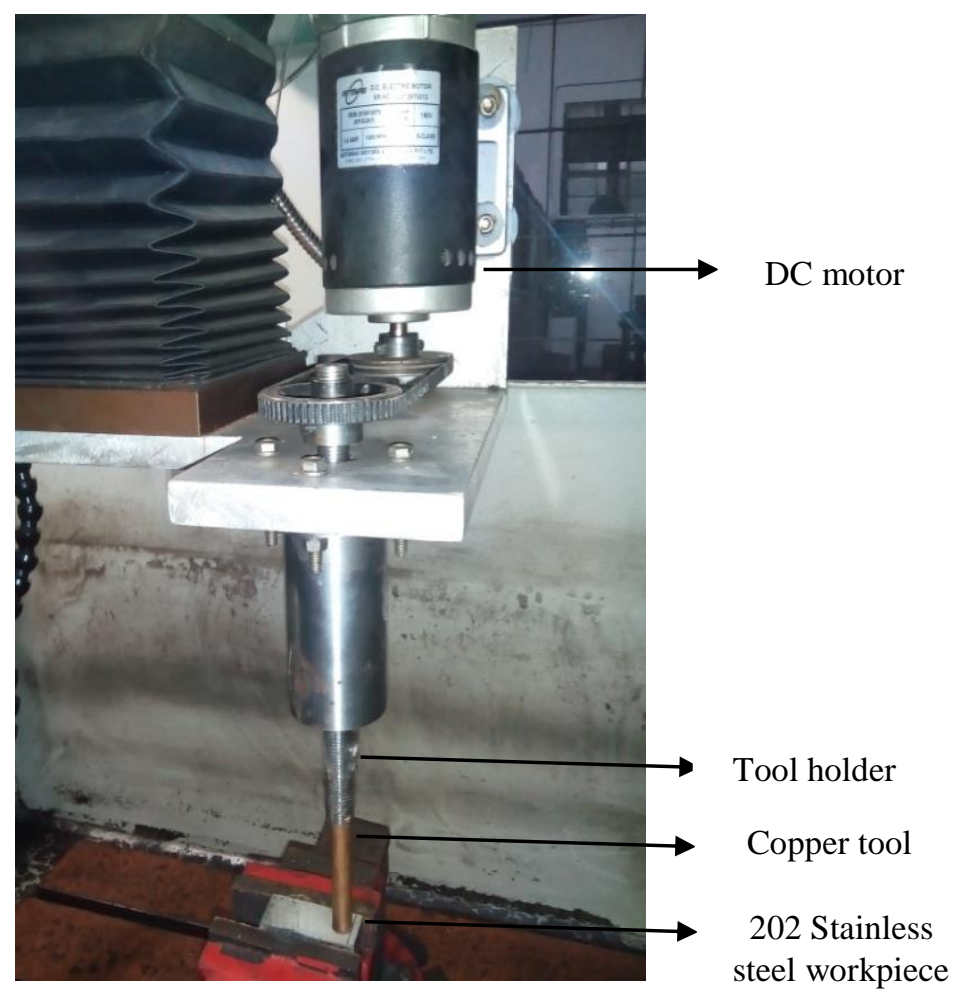

Fig.2 Drilling setup assembled on EDM machine

Table 1

Material composition of stainless steel 202G

\begin{tabular}{ll}
\hline Element & Weight \% \\
\hline Carbon & 0.15 \\
Manganese & $7.2-10$ \\
Silicon & 1 \\
Chromium & $17-19$ \\
Nickel & $4-6$ \\
Phosphorous & 0.06 \\
Sulphur & 0.03 \\
Nitrogen & 0.25
\end{tabular}


ELK

Asia Pacific Journals

Table 2

Process variables and their levels

\begin{tabular}{lllll}
\hline Parameters & Units & $\begin{array}{c}\text { Lev } \\
\text { el1 }\end{array}$ & $\begin{array}{l}\text { Lev } \\
\text { el }\end{array}$ & $\begin{array}{l}\text { Lev } \\
\text { el }\end{array}$
\end{tabular}

\begin{tabular}{lllll} 
& & & 2 & 3 \\
\hline Pulse current(I) & A & 10 & 15 & 20 \\
$\begin{array}{l}\text { Pulse on } \\
\text { time }\left(\mathrm{T}_{\text {on }}\right)\end{array}$ & $\mu \mathrm{s}$ & 50 & 70 & 90 \\
$\begin{array}{l}\text { Pulse off } \\
\text { time }\left(\mathrm{T}_{\text {off }}\right)\end{array}$ & $\mu \mathrm{s}$ & 40 & 60 & 80 \\
$\quad \mathrm{rpm}$ & 500 & 600 & 700 \\
$\quad$ & & & & \\
Tool rotation(N) & & &
\end{tabular}

\section{RESULT AND DISCUSSION}

\section{Effect of Pulse Current on MRR}

The effect of pulse current is investigated on three levels of current values 10, 15 and 20A keeping other process parameters constant $\left(\mathrm{T}_{\text {off }} 60 \mu \mathrm{s}\right.$, tool rotation $600 \mathrm{rpm}$ at different values of pulse on time). Figure 3 shows MRR increases as pulse current increases as it is responsible for heat energy created for melting. The increase of pulse current will increase the pulse discharge energy channel diameter and hence an increase in the crater diameter and depth which in turn can improve the material removal rate. With the increase of pulse on time MRR also increases because increasing in pulse on time means discharge time of pulse increases.

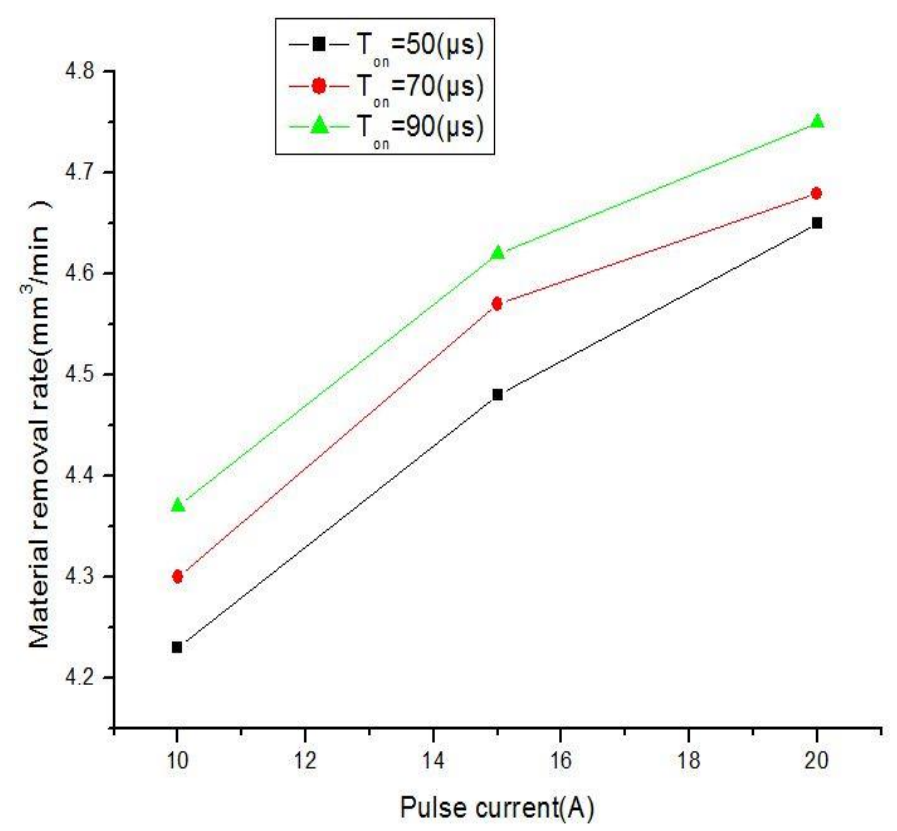

Fig.3 Effect of pulse current on MRR
ELK Asia Pacific Journals - Special Issue ISBN: 978-81-930411-4-7

\section{Effect of Pulse Current on Surface roughness}

The effect of pulse current is observed on three levels of current values 10,15 and 20A keeping other process parameters constant $\left(\mathrm{T}_{\text {off }} 60 \mu \mathrm{s}\right.$, tool rotation $600 \mathrm{rpm}$ at different values of pulse on time as shown in figure 4) .From figure it is observed that the roughness of machined surface increases as the energy of pulse increases. In other words, at higher pulse energy the metal removal rate increases and the surface will be rough. As we increase the pulse on time Ra value also increases due to increasing in duration of discharge.

\section{Effect of Pulse on time on MRR}

The effect of pulse on time is investigated on three levels of on time 50, 70 and 90 $\mu$ s keeping other process parameters constant $\left(\mathrm{T}_{\text {off }} 60 \mu \mathrm{s}\right.$, electrode rotation $600 \mathrm{rpm}$ at different values of pulse current as shown in figure 5). Figure 5 is shown that MRR increases as pulse on time increases because same energy is given for more time, increases the crater radius and depth result more material removal rate.

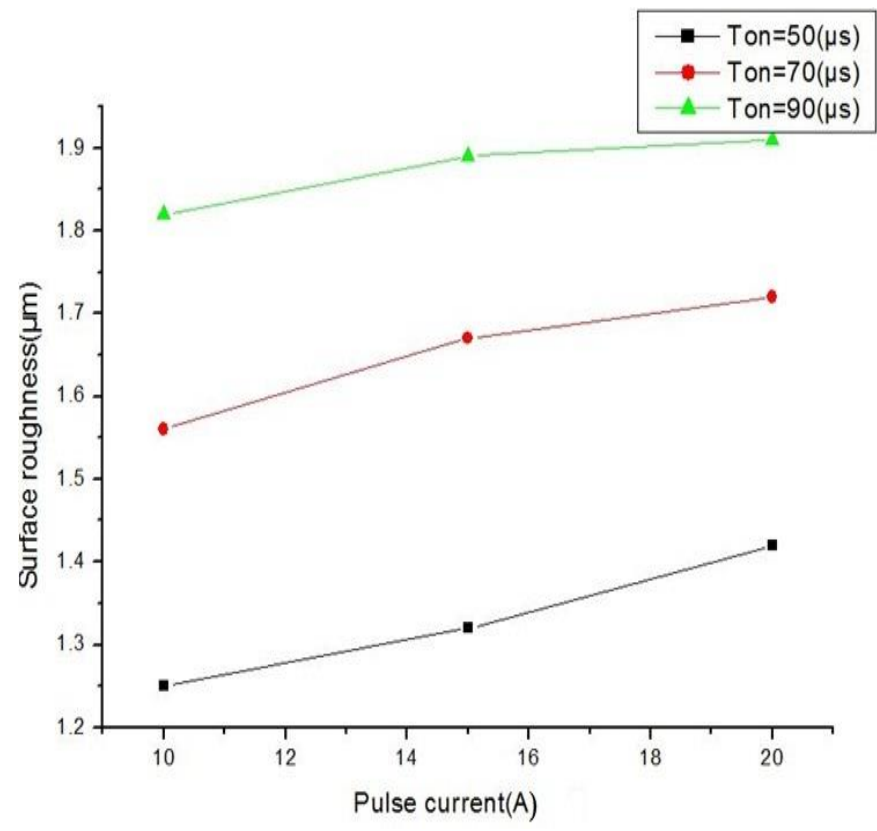

Fig.4 Effect of pulse current on surface roughness 
ELK

Asia Pacific Journals

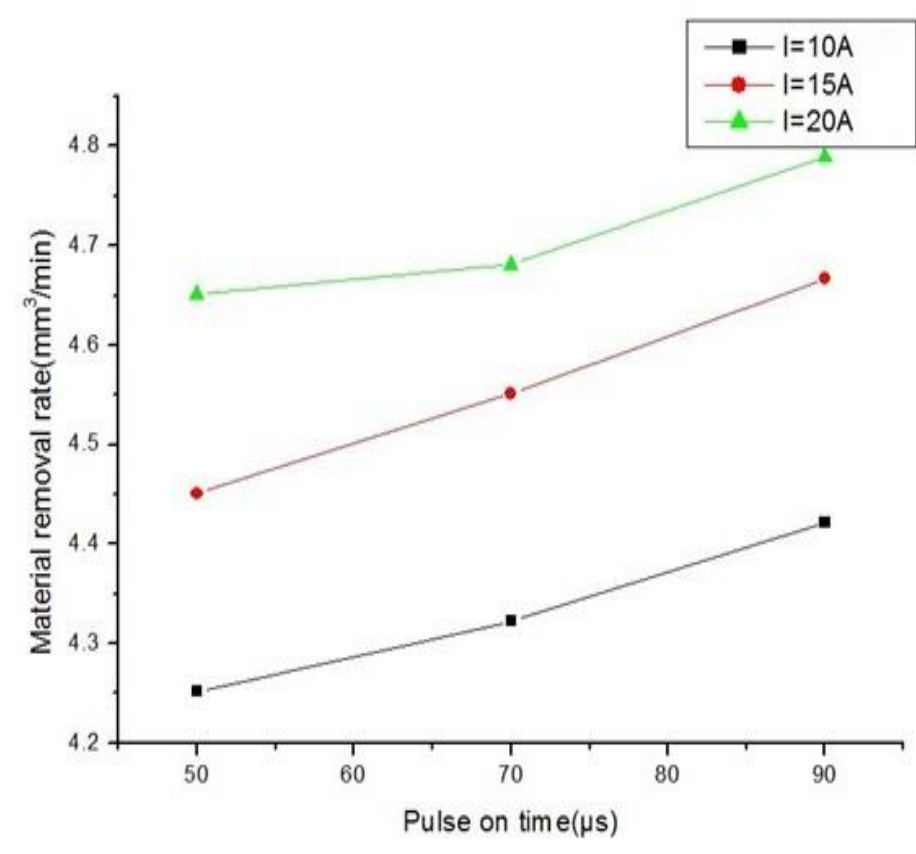

Fig.5 Effect of pulse on time on MRR

\section{Effect of Pulse on time on Surface roughness}

The effect of pulse on time is investigated on three levels of on time 50, 70 and $90 \mu$ s keeping other process parameters constant $\left(\mathrm{T}_{\text {off }} 60 \mu \mathrm{s}\right.$, tool rotation $600 \mathrm{rpm}$ at different values of pulse current as shown in figure 6).Figure shows that surface roughness increases as pulse on time increases due to large diameter and depth of crater formed because same energy is given for more time.

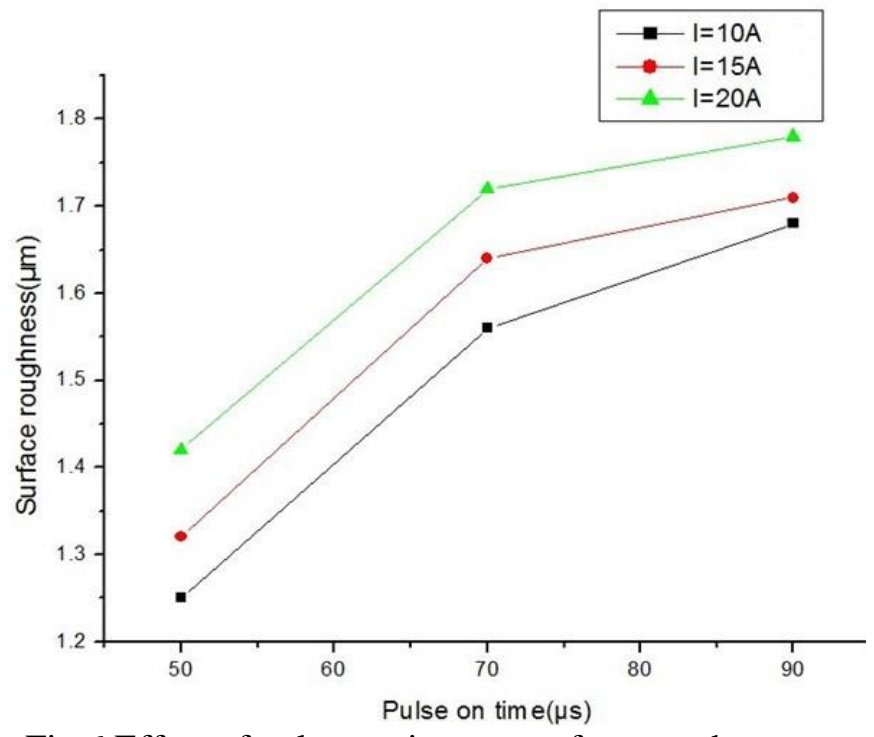

Fig.6 Effect of pulse on time on surface roughness

\section{Effect of Pulse off time on MRR}

ELK Asia Pacific Journals - Special Issue

ISBN: 978-81-930411-4-7

The effect of pulse off time is investigated on three

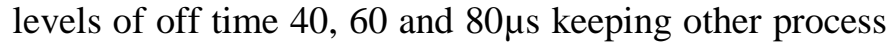
parameters constant $\left(\mathrm{T}_{\text {on }} 70 \mu \mathrm{s}\right.$, pulse current $15 \mathrm{~A}$ at different values of tool rotation as shown in figure 7).Figure shows that when we increase pulse off time material removal rate decreases because large time between two pulses takes more time in machining and cooling of workpiece. Here MRR also increases with tool rotation.

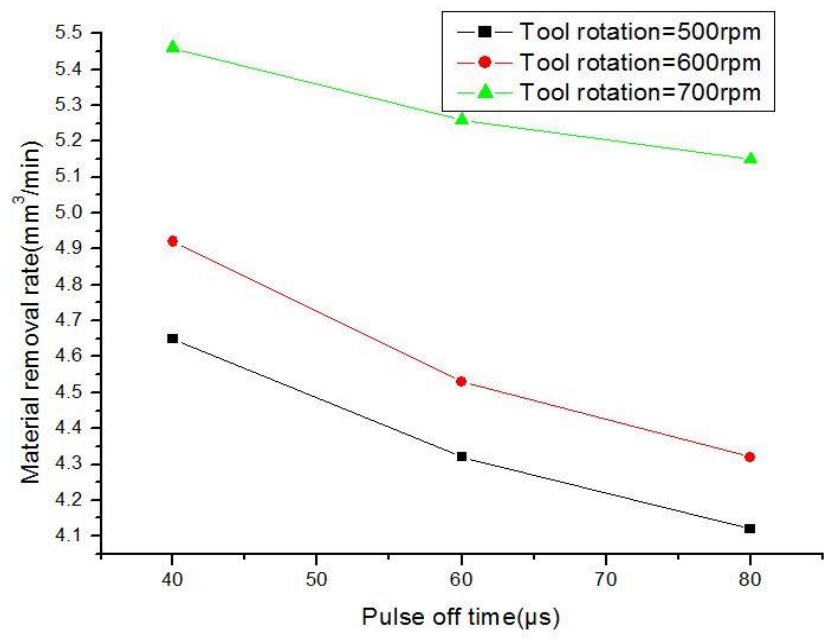

Fig.7 Effect of pulse off time on MRR

\section{Effect of Pulse off time on Surface roughness}

The effect of pulse off time is investigated on three levels of off time 40, 60 and $80 \mu$ s keeping other process parameters constant $\left(\mathrm{T}_{\text {on }} 70 \mu \mathrm{s}\right.$, pulse current $15 \mathrm{Amp}$ at different values of tool rotation as shown in figure 8).Surface roughness increases with increasing $T_{\text {off. }}$ This is due to more time between two pulses which cools the workpiece which leads to crack formation causes of high surface roughness.

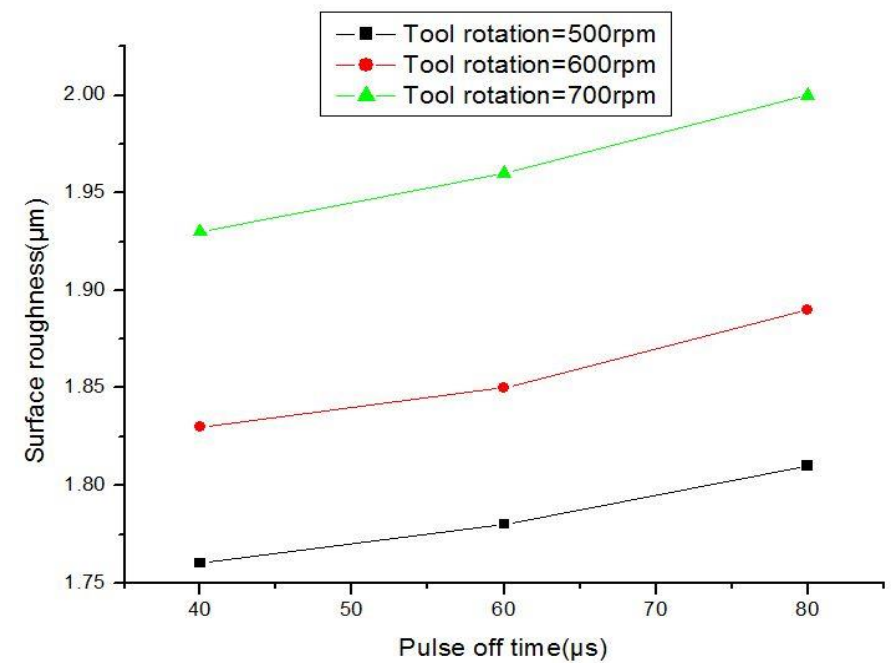

Fig.8 Effect of pulse off time on surface roughness 
ELK

Asia Pacific Journals

\section{Effect of tool rotation on MRR and surface roughness}

The effect of tool rotation is investigated on three levels of tool rotation 500, 600 and 700rpm keeping other process parameters constant $\left(\mathrm{T}_{\text {on }} 70 \mu \mathrm{s}\right.$, pulse current $15 \mathrm{~A}$ at different values of pulse off time as shown in figure $9 \& 10$ ). Figures show both material removal rate and surface roughness increase as tool rpm increases. High tool rotation provides better flushing condition and stability of spark so material removal rate increases. It leads to increase in surface roughness. As pulse off time increases it takes more time between two pulses and cools to workpiece which leads to crack formation and gives high surface roughness.

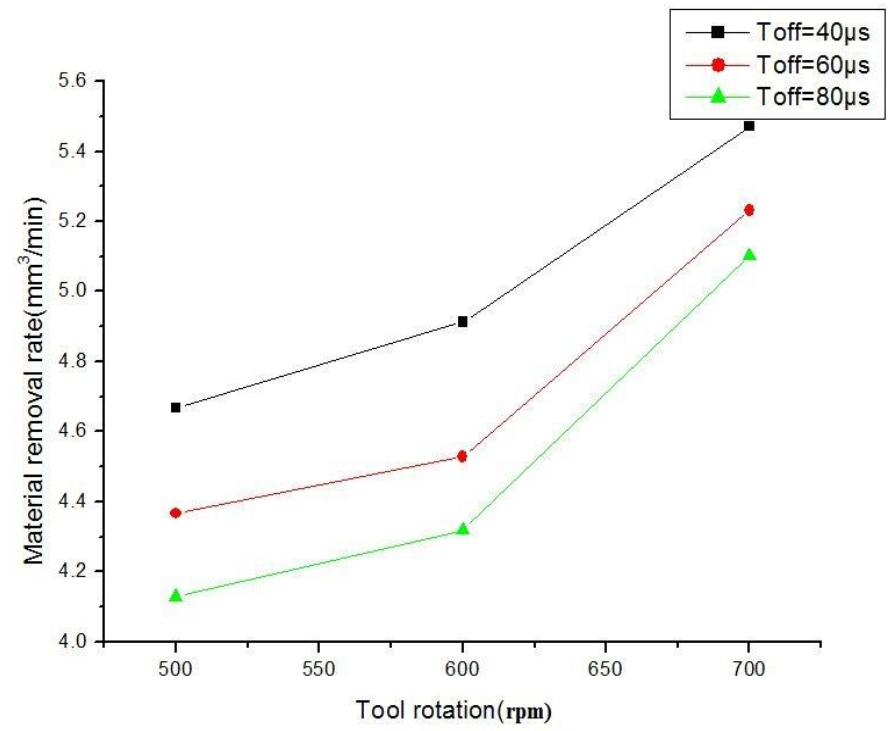

Fig.9 Effect of tool rotation on MRR

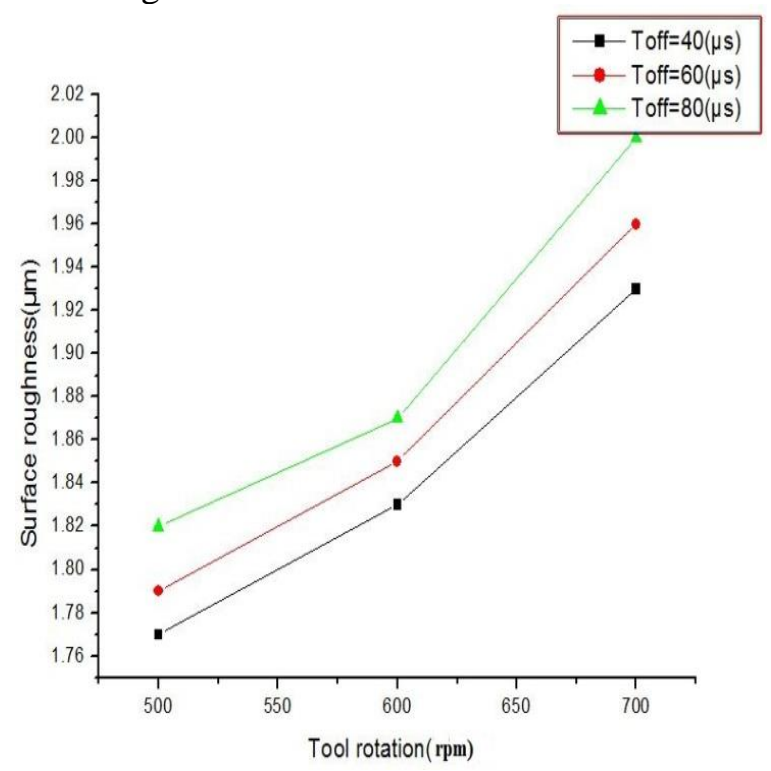

Fig.10 Effect of tool rotation on surface roughness
ELK Asia Pacific Journals - Special Issue ISBN: 978-81-930411-4-7

\section{CONCLUSIONS}

From the above study some conclusions can be drawn:

$>$ Material removal rate and surface roughness increase with increasing pulse current. For the better surface there should be low value of current which leads to lower the productivity.

$>$ Material removal rate and surface roughness increase with increasing pulse on time. So low pulse on time needed for better surface finish but it decreases MRR.

$>$ Material removal rate decreases with increasing pulse off time and surface roughness increases with increasing pulse off time.

$>$ Material removal rate as well as surface roughness increase with increasing tool rotation.

$>$ So for higher MRR there should be high pulse current, high pulse on time, high RPM and low pulse off time.

$>$ For the better surface finish there should be low pulse current, low pulse on time, low pulse off time and low RPM.

\section{References}

[1] M.S.Sohani, V.N.Gaitonde, B.Siddeswarappa, A.S.Deshpande, Investigation into the effect of tool shapes with size factor consideration in sink electrical discharge machining (EDM) process, Int $\mathbf{J}$ Adv Manuf Technol (2009) 45:1131-1145.

[2] Viral B. Prajapati, H.G. Rajput, A Review on Optimization of Process Parameters for Improving Performance in Electrical Discharge Machining, Int. Journal of Engineering Research and Applications, 2014, Vol. 4, Issue 2( Version 1) February 2014, pp.331-336.

[3] M. Kiyak, O. Cakir, Examination of machining parameters on surface roughness in EDM of tool steel, 2007, Journal of Materials Processing Technology 191 (2007) 141-144.

[4] Singh Jaspreet, Singh Mukhtiar and Singh Harpreet, Optimization of machining parameters of Electric Discharge Machining for 202 stainless steel,2013, International Journal of Modern Engineering Research (IJMER), Vol. 3, Issue. 4, Jul - Aug. 2013 pp-2166-2169.

[5] T. Muthuramalingam, B.Mohan, Experimental Investigation of Pulse Generators in Electrical Discharge Machining, 2013, Proceeding of the "National Conference on Emerging Trends in Mechanical Engineering 2k13".

[6] Pramod Malhotra and Amit Kohli, Performance Study of Electrical Discharge Machining With H-11 Tool Steel Using One Variable at a Time Approach,2013, "International Journal for Science and Emerging Technologies with Latest Trends"129(1):15-20(2013).

[7] Harpreet Singh, Amandeep Singh, Effect of Pulse On/Pulse Off Time On Machining Of AISI D3 Die Steel Using Copper And Brass Electrode In 
ELK

\section{Asia Pacific Journals}

Journal of Engineering and Science ISSN: 22784721, Vol. 1, Issue 9 (November 2012),PP19-22.

[8] Sameh S.Habib, Study of the parameters in Electrical Discharge Machining through response surface methodology approach,2009. Applied Mathematical Modelling 33(2009) 4397-4407.

[9] S.H.Tomadi, M.A.Hassan, Z. Hamedon, Member, IAENG R.Daud, A.G.Khalid, Analysis of the Influence of EDM Parameters on Surface Quality, Material Removal Rate and Electrode Wear of Tungsten Carbide,2009, Proceedings of the International Multi-Conference of Engineers and Computer Scientists 2009 Vol II,IMECS 2009, March 18 - 20, 2009, Hong Kong.

[10] Subramanian Gopalakannan, Thiagarajan Senthilvelan, Effect of Electrode Materials on Electric Discharge Machining of 316 L and 17-4 PH Stainless Steels, Journal of Minerals and Materials Characterization and Engineering, 2012, 11, 685690.

[11] Ahmet Hascalik, Ulas, Caydas, Electrical discharge machining of titanium alloy (Ti-6Al-4V), Applied Surface Science 253 (2007) 9007-9016.
ELK Asia Pacific Journals - Special Issue

ISBN: 978-81-930411-4-7

[12] I. Puertas , C.J. Luis, G. Villa, Spacing roughness parameters study on the EDM of silicon carbide, Journal of Materials Processing Technology 164165 (2005) 1590-1596.

[13] Chandramouli S, Shrinivas Balraj U and Eswaraiah $\mathrm{K}$, Optimization of Electrical Discharge Machining Process Parameters Using Taguchi Method,2014. International Journal of Advanced Mechanical Engineering, ISSN 2250-3234 Volume 4, Number 4 (2014), pp. 425-434@ Research India Publications.

[14] Reza Atefi, Ali Razmavar, Farhad Teimoori, Farshad Teimoori, The Influence of EDM Parameters in Finishing Stage on Material Removal Rate of Hot Work Steel Using Artificial Neural Network,2012, J. Basic. Appl. Sci. Res., 2(3)23072311, 2012@ 2012, Text Road Publication.

[15] C.H.Che

Haron,J.A.Ghani,Y.Burhanuddin,Y.K.Seong,C.Y.S wee,Copper and grahite electrode performance in electrical-discharge machining of XW42 tool steel, Journal of Materials Processing Technology 201 (2008) 570-573. 